\title{
SERENDIPITET U INFORMACIJSKOM PONAŠANJU ILI SLUČAJNO NAILAŽENJE NA INFORMACIJE
}

\author{
SERENDIPITY IN INFORMATION BEHAVIOR \\ OR ACCIDENTAL INFORMATION ENCOUNTERING
}

\author{
Mirta Matošić \\ Sveučilišna knjižnica u Splitu \\ mmatosic@svkst.hr
}

\author{
UDK / UDC 004.738.52: 025.4.036 \\ Pregledni rad / Review paper \\ Primljeno / Received: 4. 12. 2018. \\ Prihvaćeno / Accepted: 10. 5. 2019.
}

\section{Sažetak}

Cilj. Predstaviti koncept serendipiteta ili nailaženja na informacije, staviti ga u kontekst informacijskog ponašanja, razmotriti poticaje za istraživanje te dati pregled literature u kojoj se obrađuje tema serendipiteta u informacijskom ponašanju, kao i one u kojoj se definira pojam serendipiteta. Isto tako, cilj je predstaviti i radove u kojima se promišlja primjena koncepta serendipiteta u pretraživanju informacija te u edukaciji o informacijskoj pismenosti.

Pristup/metodologija. Pregled relevantne literature vezane uz pojam serendipiteta, sinteza dosadašnjih istraživanja i kritičko promišljanje o temi.

Rezultati. Predstavljen je pojam serendipiteta u kontekstu informacijskog ponašanja, ali i njemu srodni pojmovi kao što su slučajno nailaženje na informacije i serendipno pronalaženje informacija te drugi. Iako se s proučavanjem serendipiteta u informacijskim znanostima počelo tek relativno nedavno, do danas je izrađeno nekoliko modela informacijskog ponašanja koji uključuju slučajno nailaženje na informacije, kao i samostalnih modela slučajnog nailaženja na informacije. U ovom je radu predstavljen pregled takvih modela.

Vjesnik bibliotekara Hrvatske 62, 1(2019), 219-236

ISSN 0507-1925

(C) VBH 2018. 
Originalnost/vrijednost. Ovaj rad predstavlja sintezu dosadašnjih istraživanja na temu serendipiteta te opisuje najnovije trendove u istraživanju teme. Također, ovo je prvo predstavljanje fenomena serendipiteta u kontekstu informacijskog ponašanja hrvatskoj znanstvenoj i stručnoj zajednici na hrvatskom jeziku.

Ključne riječi: informacijsko ponašanje, serendipitet, traženje informacija

\begin{abstract}
Objective. The goal of the paper is to present the concept of serendipity, or information encountering, and to put it in the context of information behavior while considering incentives for its research and providing an overview of literature dealing with the topic of serendipity in information behavior, as well as with its definition. Furthermore, the aim is to review literature focusing on the application of the concept of serendipity in information retrieval, and in information literacy education.
\end{abstract}

Approach / Methodology: A review of relevant literature related to the concept of serendipity, synthesis of previous research and critical analysis of the subject.

Findings. The term serendipity is presented in the context of information behavior, as are the related terms such as accidental information discovery, serendipitous information retrieval, and others. Despite the fact that researchers have only recently begun to address serendipity in information science, so far several models of information behavior that include serendipity have been developed, as have the stand-alone serendipity models. An overview of such models is presented in this paper.

Originality / Value. This paper presents the synthesis of previous research on the topic of serendipity and describes the latest trends in the research. This is the introduction of the serendipity phenomenon in the context of information behavior to the Croatian scientific and professional community written in Croatian.

Keywords: information behavior, information searching, serendipity

\title{
1. Uvod
}

Serendipitet je pojam koji dolazi od engleske riječi serendipity, a opisuje slučajno pronalaženje zanimljivih ili vrijednih stvari (informacija) ${ }^{1}$. U informacijskim znanostima taj se pojam uglavnom susreće u području informacijskog ponašanja korisnika. U opisima modela informacijskog ponašanja koncept serendipiteta ne spominje se često jer, iako se prema Fosteru i Fordu smatra vrijednim, on je u isto vrijeme nedostižan i nepredvidiv te se, barem na prvi pogled, ne može kontrolirati i ,koristiti“ kao strategija traženja informacija te je nepogodan za istraživanje jer u

1 SERENDIPITY | Meaning in the Cambridge English Dictionary." 
svojoj prirodi nije podložan sustavnoj kontroli i predviđanju. Foster i Ford nadalje spekuliraju da možda upravo iz tog razloga autori u području informacijskih znanosti nisu uvrštavali serendipitet $u$ modele traženja informacija $i$ informacijskog ponašanja. ${ }^{2}$ Poticaj za relativno recentan početak proučavanja serendipiteta može se naći i u današnjem informacijsko-tehnološkom okruženju koje potencira susretanje informacija. McCay Peet i Toms navode kako su se razlozi za ispitivanje fenomena serendipiteta pojavili tijekom posljednjih 25 godina te da su tehnološke promjene pružile i poticaj i inspiraciju za istraživanja u kojima se ispituje kako se ljudi prilagođavaju, koriste ga i utječu na digitalno okruženje, odnosno kako ga oblikuju u svrhu bolje podrške serendipitetu u kontekstu učenja, svakodnevnog života, poslovanja, znanosti, prava i provođenja slobodnog vremena. ${ }^{3}$ Oni nadalje navode kako se mijenja pristup tehnologiji te kako njezin odnos sa serendipitetom prelazi iz široke konceptualizacije i usporedbe prilika za serendipitet u fizičkom, odnosno virtualnom informacijskom okruženju prema nijansiranom pristupu koji odražava sve veću složenost tehnologije, kao i naše interakcije s njom. ${ }^{4}$ Budući da je u povijesti do mnogih značajnih znanstvenih otkrića došlo upravo slučajnim sretnim pronalaskom informacija, autorica ovog rada smatra da je potrebno pobliže razmotriti taj oblik informacijskog ponašanja. Brojni su razlozi za proučavanje serendipiteta, a među ostalima tu su učestalost njegove pojave te njegova primjena. Bates primjerice spekulira da se čak oko osamdeset posto znanja stječe nenamjernim nailaženjem na informacije. ${ }^{5}$ Iako je teško govoriti o primjeni nečeg što je nepredvidivo, neki znanstvenici, kao primjerice Toms, predlažu da se sustavi za pretraživanje informacija dizajniraju s mogućnošću serendipnog pretraživanja ${ }^{6}$, dok Erdelez, Basic i Levitov ${ }^{7}$, kao i Ryder i Nutefall ${ }^{8}$, proučavaju mogućnosti

2 Usp. Foster, A.; N. Ford. Serendipity and information seeking: an empirical study. // Journal of Documentation 59, 3(2003), str. 321. DOI: https://doi.org/10.1108/00220410310472518.

${ }^{3}$ Usp. McCay-Peet L.; E. G. Toms. Researching serendipity in digital information environments. San Rafael, California: Morgan \& Claypool Publishers, 2017. Str. 11.

${ }^{4}$ Usp. isto, str. 22.

${ }^{5}$ Usp. Bates, M. Toward an integrated model of information seeking and searching. // New Review of Information Behaviour Research (predstavljeno na Fourth international Conference on Information Needs, Seeking and Use in Different Contexts, Lisbon, Portugal, 2002, Dostupno i na: https://pages.gseis.ucla.edu/faculty/bates/articles/info_SeekSearch-i-030329.html [citirano 2018-9-15].

${ }^{6}$ Usp. Toms, E. Serendipitous information retrieval. // Proceedings of the First DELOS Network of Excellence Workshop on Information Seeking, Searching and Querying in Digital Libraries. Zurich, 11.-12. prosinca, 2000., str. 20. Dostupno i na: https://www.ercim.eu/publication/ws-proceedings/DelNoe01/3_Toms.pdf.

7 Usp. Erdelez, S.; J. Basic; D. D. Levitov. Potential for inclusion of information encountering within information literacy models. // Information Research 16, 3(2011). Dostupno na: http:// informationr.net/ir/16-3/paper489.html. [citirano:2018-9-15].

${ }^{8}$ Usp. Ryder, P. M.; J. Nutefall. Teaching serendipity. //Accidental Information Discovery: Cultivating Serendipity in the Digital Age / ed. by Race, T.M.; Makri, S. Cambridge: Elsevier: Chandos Publishing, 2016. Str. 27-51. 
uključivanja slučajnog nailaženja na informacije, odnosno serendipnog pronalaženja informacija, u modele podučavanja informacijske pismenosti. Nakon predstavljanja koncepta serendipiteta, u ovom radu razmotrit će se i njegova primjena $\mathrm{u}$ razvoju informacijskih sustava te u podučavanju informacijskoj pismenosti.

\section{Serendipitet - od bajke do nove riječi}

Engleska riječ serendipity označava sposobnost ili fenomen pronalaženja vrijednih ili potrebnih stvari koje nisu tražene. ${ }^{9}$ Ponekad je značenje riječi opisano kao pronalaženje nečeg vrijednog dok se traga za nečim sasvim drugim ili kao pronalaženje nečeg na neočekivanom mjestu ili na neočekivan način. Riječ je uvijek o „sretnoj slučajnosti““. Anić i Goldstein u Rječniku stranih riječi nude prijevod te riječi kao serendipitet te ga opisuju kao umijeće da se slučajno dođe do zanimljivih i značajnih otkrića. ${ }^{10}$ Većini riječi ne može se utvrditi točan dan i način nastanka, no nastanak riječi serendipity detaljno je dokumentiran. Engleski pisac i političar Horace Walpole 28. siječnja 1754. godine napisao je pismo svojemu prijatelju Horaceu Mannu o slučajnom pronalasku nekog detalja dok je istraživao stare grbove te je taj pronalazak nazvao serendipnim. U pismu navodi kako „nije imao ni o čem boljem pisati“ te nastavlja opisivati što misli pod tim pojmom i kako je do njega došao. Jednom davno pročitao je bajku o Tri princa od Serendipa (Serendip je povijesno ime za Šri Lanku, op. a.), a koji su na svojim pustolovinama mudrošću i slučajnošću uvijek dolazili do otkrića koja nisu ni tražili. Njegov slučajni pronalazak asocirao ga je na tu priču, a riječ koju je izmislio kako bi ga opisao bila je serendipity. ${ }^{11}$ Taj izraz međutim nije zaživio u engleskom jeziku sve do početka dvadesetog stoljeća, kada se povremeno počeo pojavljivati u literaturi, da bi devedesetih godina postao uvriježen u standardnom jeziku, pa čak i popularan. ${ }^{12}$

\section{Serendipitet u znanosti i vrste serendipiteta}

Do mnogih vrijednih otkrića u znanosti došlo se sretnim slučajem. Pripovijeda se da je Newton šećući vrtom, ne baveći se u tom trenutku nekim istraživanjem, primijetio jabuku koja je pala sa stabla na tlo te ga je ta slu-

\footnotetext{
${ }_{9}$ Usp. Definition of serendipity [citirano 2018-9-11] Dostupno na: https://www.merriam-webster. com/dictionary/serendipity.

${ }_{10}$ Anić, V.; I. Goldstein. Rječnik stranih riječi. Dotiskano 2. izd., Zagreb: Novi Liber, 2009. Str. 1045.

11 Usp. Merton, R. K.; E. G. Barber. The travels and adventures of serendipity: a study in historical semantics and the sociology of science. Princeton, N.J: Princeton University Press, 2004. Str. $1-3$.

12 Usp. Serendipity: how the vogue word became vague. Dostupno na: http://livingheritage.org/ serendipity.htm [citirano: 2018-9-11].
} 
čajnost potaknula na razmišljanje i, u konačnici, otkrivanje gravitacijske sile. Fleming je pak aktivno radio na pronalasku lijekova, no slučajno mu je spora plijesni upala u Petrijevu zdjelicu te zaustavila širenje bakterije stafilokoka koja je bila u posudici. Na temelju toga Fleming je zaključio da ta plijesan (lat. penicillium) ima antibakterijska svojstva te je iz nje, nakon nekog vremena, izolirao penicilin. Proces vulkanizacije također je otkriven sretnim slučajem dok je znanstvenik Goodyear istraživao način kako učiniti automobilske gume izdržljivijima. Popis je sretnih otkrića (informacija) u znanosti dug, no informacijske se znanosti donedavno nisu posebno bavile slučajnim otkrićima informacija. Serendipitet je bio češća tema u povijesti znanosti nego u informacijskim znanostima pa je tako Friedel, povjesničar znanosti koji se bavio serendipitetom, predložio podjelu vrsta serendipiteta na kolumbovski, arhimedovski i galilejevski. Kolumbo je tražio Indiju, ali je umjesto Indije pronašao Ameriku. Kolumbovski je serendipitet kad se u potrazi za jednom vrijednošću pronađe neka druga te se prepozna kao vrijednost. Arhimed je u kadi riješio problem kojim se trenutno bavio, a to je bilo kako izračunati volumen nepravilnog krutog tijela, iako nije s tom namjerom ušao u kadu. Arhimedovski je serendipitet pronalaženje traženog rezultata, ali ne logičkom dedukcijom, već igrom slučaja. Ne znamo što je Galileo očekivao vidjeti kroz teleskop, ali ono što je vidio rezultiralo je otkrićem dotad nepoznatih nebeskih tijela. Galilejevski je serendipitet otkrivanje vrijednih informacija koje nismo tražili. ${ }^{13}$ Slično tomu, McCay-Peet i Toms opisuju tri načina na koje može doći do serendipnih otkrića, odnosno tri tipa serendipiteta. Tip A je kad osoba dolazi do zapažanja koje u konačnici vodi do otkrića nečeg novog, a da ni zapažanje ni ishod nisu cilj istrage. Tip B je kad osoba traži rješenje nekog problema, ali umjesto rješenja tog problema nađe rješenje nekog drugog problema. I konačno, tip C je kad osoba traži rješenje nekog problema, ali to rješenje ne dođe iz očekivanog izvora ili smjera ${ }^{14}$ Friedelova podjela vrsta serendipiteta vrlo nalikuje podjeli do koje su došli McCay-Peet i Toms. Kolumbovskom serendipitetu kod Friedela odgovara tip B iz podjele McCay-Peet i Toms gdje se u potrazi za jednom vrijednošću pronalazi neka druga. Erdelezino nailaženje na informacije također odgovara tipu B prema McCay-Peet i Toms. ${ }^{15}$ Arhimedovski serendipitet odgovara tipu $\mathrm{C}$ gdje se u potrazi za nekim rješenjem do njega dođe, ali neočekivanim putem, dok galilejevski serendipitet nalikuje tipu A gdje se dolazi do nekog otkrića bez da su zapažanje ili ishod bili cilj neke potrage.

${ }^{13}$ Usp. Friedel, R. Serendipity is no accident. // The Kenyon Review 23, 2(2001), str. 38-40.

${ }^{14}$ Usp. McCay-Peet L.; E. G. Toms. Nav. dj., str. 36-38.

15 Usp. Erdelez, S. Information encountering: it's more than just bumping into information. // Bulletin of the American Society for Information Science and Technology 25, 3(1999), str. 25. DOI: https://doi.org/10.1002/bult.118. 


\section{Informacijsko ponašanje - koncept i razvoj područja}

U području informacijskih znanosti serendipitet ili serendipno pronalaženje informacija važna je komponenta složenog fenomena koji nazivamo traženjem informacija (engl. information seeking) ${ }^{16}$, a koje je prema Wilsonovu ugniježđenom modelu podskup informacijskog ponašanja (engl. information behavior). Wilson u spomenutom modelu opisuje koncept informacijskog ponašanja pomoću ugniježđenih podskupova pa smješta pretraživanje informacija (engl. information searching) unutar traženja informacija, koje je pak smješteno unutar informacijskog ponašanja. ${ }^{17}$

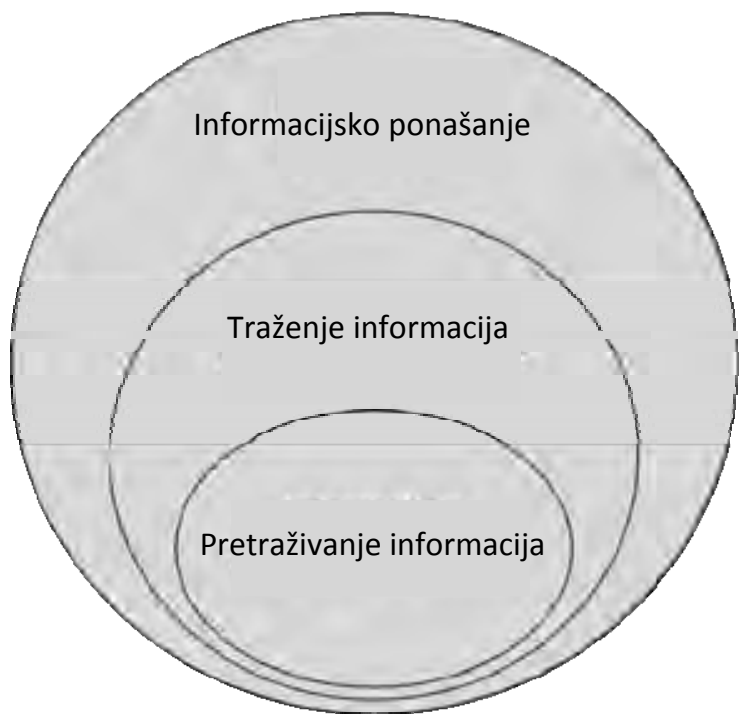

Slika 1. Wilsonov ugniježđeni model informacijskog ponašanja ${ }^{18}$

Za podrobno pojašnjavanje termina serendipitet potrebno je prvo pojasniti koncept informacijskog ponašanja, a ono se definira kao ljudsko ponašanje $u$ odnosu na informacijske izvore i kanale te uključuje aktivno i pasivno traženje informacija, kao i korištenje tih informacija. ${ }^{19}$ Prema Caseu informacijsko ponašanje obuhvaća traženje informacija te cjelokupnost drugih nenamjernih ili pasivnih ponašanja (kao što je nailaženje na informacije), kao i namjerno ponašanje koje ne

\footnotetext{
${ }^{16}$ Usp. Foster; F. Nav. dj., str. 337.

17 Usp. Wilson, T. D. Models in information behaviour research. // The Journal of Documentation 55, 3(1999), str. 263.

18 Usp. isto.

19 Usp. Wilson, T. D. Human information behavior. // Informing Science: The International Journal of an Emerging Transdiscipline 3,2(2000), str. 49.
} 
uključuje traženje poput aktivnog izbjegavanja informacija. ${ }^{20}$ Serendipno je stjecanje informacija kao pasivno ili nenamjerno stjecanje informacija dakle jedan od vidova informacijskog ponašanja. Uže područje proučavanja informacijskog ponašanja koje nazivamo traženjem informacija jest ono koje se bavi serendipitetom ili nailaženjem na informacije.

\section{Serendipitet u kontekstu informacijskog ponašanja}

Iako je proučavanje serendipiteta metodološki problematično jer je izuzetno složeno replicirati pojavu serendipiteta u kontroliranim uvjetima, nekoliko eminentnih znanstvenika iz polja informacijskih znanosti bavi se tim područjem te su u svojim radovima ponudili nekoliko definicija tog koncepta. Erdelez se koristi pojmom susretanja s informacijama, a opisuje ga kao upečatljivo iskustvo neočekivanog otkrića korisne ili zanimljive informacije. ${ }^{21}$ Susretanje s informacijama događa se kad osoba traži informaciju koja se odnosi na jednu temu, a nađe informaciju koja se odnosi na drugu. Isto tako, susretanje s informacijama događa se i tijekom obavljanja neke rutinske aktivnosti. ${ }^{22}$ Erdelez stoga definira nailaženje na informacije kao ,slučajno otkrivanje informacija tijekom aktivnog traženja nekih drugih informacija“. ${ }^{23}$ Williamson također istražuje serendipitet u kontekstu informacijskog ponašanja, ali koristi termin slučajno prikupljanje informacija (engl. incidental information acquisition) te ga poistovjećuje s nenamjernim otkrivanjem informacija (engl. accidental information discovery). ${ }^{24}$ Mnogi znanstvenici koji se bave informacijskim ponašanjem bave se izvorištem informacijskih potreba, pa tako primjerice Dervin i Nilan govore o ,informacijskom jazu“, Khulthau o „umanjivanju nesigurnosti“, a Belkin o „nepravilnom stanju znanja“. Međutim Williamson naglašava da nije svako informacijsko ponašanje namjerno i da na mnoge informacije ljudi nailaze u svakodnevnom životu bez da ih namjerno traže. Williamson nadalje tvrdi da ljudi susreću potrebne informacije promatranjem svijeta oko sebe te da nekih informacijskih potreba postaju svjesni tek kad otkriju relevantne informacije. ${ }^{25}$ Savolainen također koristi pojam slučajno prikupljanje informacija te ga stavlja u odnos s pretraživanjem informacija koje se razlikuje od

20 Usp. Case, D. O. Looking for information: a survey of research on information seeking, needs, and behavior. Bingley, UK: Emerald, 2012. Str. 5.

${ }^{21}$ Usp. Erdelez, S. Information Encountering. // Theories of Information Behavior / ed. by Fisher, K., Erdelez, S. i McKechnie, L. Medford, N.J: Information Today Inc. 2005. Str. 179.

22 Usp. Isto, str 25.

23 Erdelez, S. Investigation of information encountering in the controlled research environment. // Information Processing \& Management 40, 6(2004), str. 1015.

24 Usp. Williamson, K. Discovered by chance: the role of incidental information acquisition in an ecological model of information use. // Library \& Information Science Research 20, 1(1998), str. 24.

25 Usp. Williamson, K. Ecological theory of human information behavior. // Theories of Information Behavior / ed. by Fisher, K., Erdelez, S. i McKechnie, L. Medford, N.J: Information Today Inc. 2005. Str. 128-129. 
slučajnog prikupljanja informacija po tome što prvo označava primanje informacija, dok drugo naglašava namjerno traženje. ${ }^{26}$ Agarwal u svom radu Toward the definition of serendipity in information behavior polazi od pet zaključaka o serendipitetu preko kojih dolazi do definicije pojma. Pet zaključaka od kojih Agarwal polazi jesu sljedeći: 1) (Serendipitet) se može dogoditi u vrijeme kad je osoba u pasivnom, neusmjerenom modalitetu pretraživanja (odnosno ne traži ništa posebno - Newtonov scenarij) ili u aktivnom, usmjerenom modalitetu (Flemingov scenarij). 2) Samo serendipno otkriće uvijek je slučaj ili okidač prilike, nakon čega slijedi razdoblje inkubacije, kad dolazi do povezivanja razumijevanja i vrijednosti novih informacija. To se događa kada je visceralna ili svjesna potreba za informacijama zadovoljena. 3) Serendipno pronalaženje informacija dovodi do neočekivanoga, iznenađenja ili aha-trenutka, ali može dovesti i do razočaranja. 4) Što je neočekivaniji, informativniji i vrjedniji pronalazak, to je veći stupanj serendipiteta. 5) Stupanj iznenađenja (aha-trenutak) bit će veći kad je osoba u stanju prirodne pozornosti, za razliku od stanja serendipne pozornosti ili stanja pripremljenog uma. Iz navedenih pet zaključaka Agarwal izvodi definiciju serendipiteta kao slučajnog, neočekivanog otkrića informacija koje dovodi do aha-trenutka pozorne osobe u pasivnom, nepozornom stanju ili u aktivnom, pozornom stanju, nakon čega dolazi razdoblje inkubacije, a potom slijedi spoznavanje i pronalazak vrijednosti. ${ }^{27}$ Slično Agrawalovoj definiciji, i McCay-Peet i Toms tvrde kako događaj, da bi se nazvao serendipnim, mora započeti zapažanjem nečeg neočekivanog (neobičnog, nepredviđenog, nepravilnog), a opažatelj mora biti vješt u prepoznavanju nepravilnosti u zapaženome i imati mentalni sklop koji će ga poticati da nastavi s promatranjem koliko je god potrebno da bi se došlo do neočekivanog značajnog otkrića. ${ }^{28}$ Nedvojbeno je da je serendipitet ili slučajno prikupljanje informacija oblik informacijskog ponašanja do kojeg dolazi nenamjerno, no terminologija za taj koncept nije usuglašena. Autori se uglavnom ne bave definiranjem koncepta, osim Erdelez koja definira nailaženje na informacije i Agarwala koji predlaže definiciju serendipiteta. Ostali spomenuti autori uglavnom opisuju koncept serendipiteta, no i definicijama i konceptima zajednički je opis procesa serendipiteta, pa tako svi navode početno stanje neočekivanja, zatim aha-trenutak ili eureka-efekt, kako ga naziva Erdelez, i na kraju neku vrstu vrijednog ishoda.

\footnotetext{
26 Usp. Savolainen, R. Elaborating the conceptual space of information-seeking phenomena. // Information Research 20, 3(2015). Dostupno na: http://www.informationr.net/ir/21-3/paper720 [citirano: 2018-9-15]

${ }_{27}$ Usp. Agarwal, N.K. Towards a definition of serendipity in information behaviour. // Information Research 20, 3(2015). Dostupno na: http://informationr.net/ir/203/pape5674.html [citirano:2018-9-15].

28 Usp. McCay-Peet L.; E. G. Toms. Nav. dj., str. 4.
} 


\section{Serendipitet u modelima traženja i susretanja informacija}

Modeli traženja informacija (engl: information seeking behavior) uglavnom opisuju namjerno i ciljano traženje informacija, pa tako Spink i Cole postavljaju traženje informacija kao podskup informacijskog ponašanja koji uključuje namjerno traženje informacija sa svrhom ostvarenja nekog cilja. ${ }^{29}$ Traženje informacija naglašava namjernu aktivnost, intenciju, no za ovaj rad važno je napomenuti da postoje i pasivni oblici nailaženja na informacije, odnosno susretanja s informacijama. Marcia Bates opisuje modalitete traženja informacija te uvodi i stavlja u odnos kategorije aktivnog, odnosno pasivnog i usmjerenog, odnosno neusmjerenog traženja informacija. Prema tim kategorijama, modaliteti aktivnog traženja informacija su (neusmjereno) prebiranje i usmjereno pretraživanje, a pasivnog traženja (usmjereno) promatranje i (neusmjereno) bivanje svjesnim (engl. being aware). Može se reći da su promatranje i usmjereno pretraživanje načini traženja onih informacija za koje znamo da ih trebamo, dok su prebiranje i bivanje svjesnim načini traženja onih informacija za koje ne znamo da ih trebamo. ${ }^{30}$

\begin{tabular}{|c|c|c|}
\hline & USMJERENO & NEUSMJERENO \\
\hline AKTIVNO & Pretraživanje & Prebiranje \\
\hline PASIVNO & Promatranje & Bivanje svjesnim \\
\hline
\end{tabular}

Slika 2. Prikaz modaliteta traženja informacija prema Bates $^{31}$

Savolainen primjećuje da je kategorija bivanja svjesnim preopćenita i primjenjiva na svekoliko informacijsko ponašanje te umjesto tog termina predlaže kategoriju nenamjernog stjecanja informacija (engl. incidental acquisition of information). ${ }^{32}$ Upravo je nenamjerno stjecanje informacija ${ }^{33}$, uz slučajno otkrivanje informacija ${ }^{34}$ i nailaženje na informacije ${ }^{35}$, jedan od pojmova koji se u literaturi o

\footnotetext{
29 Usp. Spink, A.; A. Cole. Human information behavior: integrating diverse approaches and information use. // Journal of the American Society for Information Science and Technology 57, 1(2006), str. 25-35.

30 Usp. Bates, M. Nav. dj., str. 1-15.

31 Usp. Isto.

32 Usp. Savolainen, R. Nav. dj.

33 Usp. Williamson, K. Discovered. Nav. dj., str. 24.

34 Usp. Accidental information discovery: cultivating serendipity in the digital age / ed. by Race, T.M.; Makri, S. Cambridge: Elsevier: Chandos Publishing, 2016.

35 Usp. Erdelez, S. Information encountering: it's more than just bumping into information. // Bulletin of the American Society for Information Science and Technology 25, 3(1999), str. 26-29. DOI: https://doi.org/10.1002/bult.118.
} 
informacijskom ponašanju naizmjenično koriste za opisivanje sličnih ili istih situacija za koje se koristi i pojam serendipitet $u$ informacijskom ponašanju.

Prema Erdelez, do susretanja s informacijama dolazi slučajno, i to dok osoba traži informaciju koja se odnosi na jednu temu, a nailazi na informaciju koja se odnosi na drugu ${ }^{36}$ Erdelez je razvila model kojim opisuje susretanje s informacijama, a koji se zasniva na pretpostavci da postoje dva problema zbog kojih se pretražuju informacije: inicijalni problem u prvom planu te problem u drugom planu, odnosno u pozadini. Njezin se model sastoji od pet koraka: 1. primjećivanje informacije potencijalno korisne za problem u drugom planu; 2. zaustavljanje i prekid inicijalnog pretraživanja; 3 . pregledavanje novopronađene informacije; 4 . bilježenje informacije ako je procijenjena kao korisna; 5. povratak inicijalnom pretraživanju.

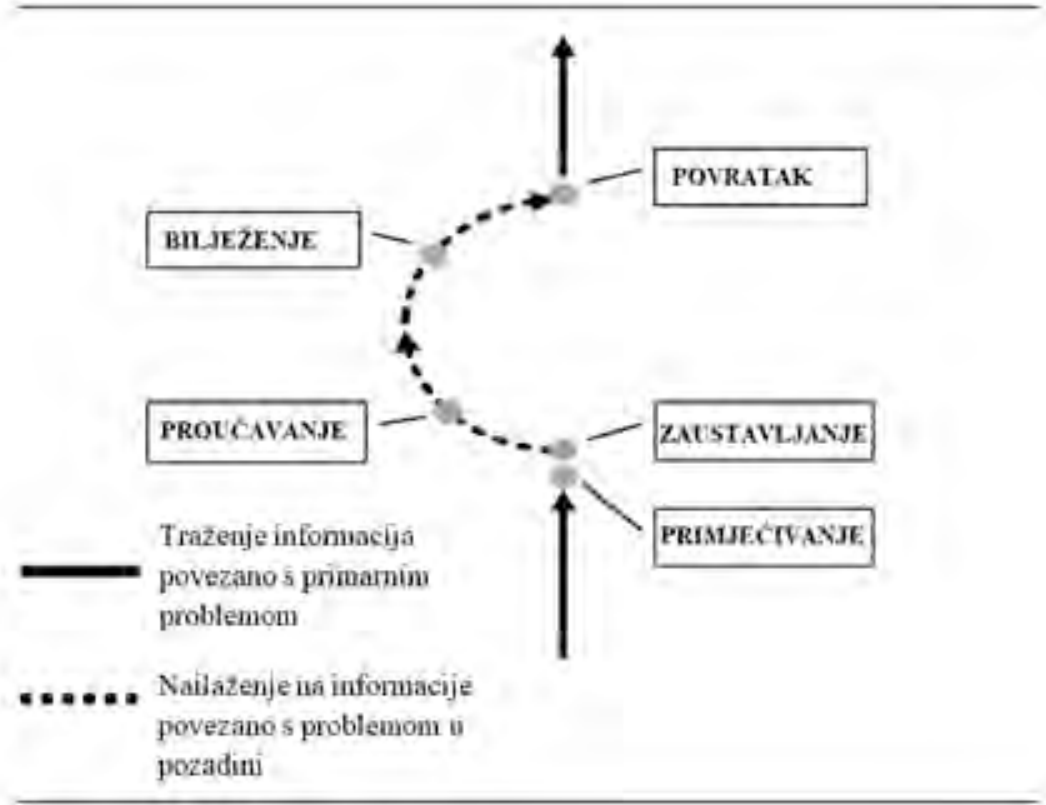

Slika 3. Prikaz nailaženja na informacije prema Erdelez ${ }^{37}$

Agarwal proširuje Wilsonov ugniježđeni model traženja informacija na način da razdvaja podskup traženja informacija u zasebne podskupove: namjerno i nenamjerno traženje informacija. Ta dva podskupa nisu odvojena te imaju područje presjeka u kojem se nalazi serendipno nailaženje na informacije za kojima osoba ima instinktivnu potrebu. ${ }^{38}$ Jiang, Liu i Chi predlažu model susretanja s

36 Usp. Erdelez, S. Investigation Usp. isto, str. 1015.

37 Usp. Isto, str.1016.

38 Usp. Agarwal, N.K. Nav. dj. 
informacijama sličan modelu koji je razvila Erdelez. One su opisale tri faze u procesu susretanja s informacijama putem interneta, a odnose se na aktivnosti prije, tijekom i nakon susretanja s informacijama. Prema njihovu modelu, aktivnosti koje prethode susretanju s informacijama, kao što su prebiranje i pretraživanje informacija, pružaju kontekst za susret s informacijama. Tijekom same aktivnosti susreta s informacijama moguće je razlikovati tri faze: primjećivanje stimulansa, proučavanje sadržaja te prikupljanje zanimljivog ili korisnog sadržaja. Naposljet$\mathrm{ku}$, informacija koju se susrelo dodatno se proučava nakon susreta kroz aktivnosti kao što su spremanje, korištenje i dijeljenje. ${ }^{39}$

Bates i Savolainen bave se modalitetima traženja informacija te naglašavaju da uz namjerno traženje informacija postoji i informacijsko ponašanje koje nije u potpunosti namjerno, već je nenamjerno i pasivno te ga nazivaju bivanjem svjesnim, odnosno nenamjernim stjecanjem informacija. Kao preduvjete stjecanju informacija navode svjesnost i osjetljivost na okolinu. Modeli koje su razvili Erdelez, Agarwal te Jiang, Liu i Chi opisuju proces susreta s informacijama, smještaju serendipitet unutar polja informacijskog ponašanja, odnosno bave se fazama serendipiteta.

\section{Očekivanje neočekivanog ili pripremljen um: preduvjeti slučajnog otkrivanja informacija}

Louis Pasteur rekao je da „sreća prati pripremljen um“ i upravo tim citatom neki znanstveni članci objašnjavaju razliku između serendipiteta i slučajnosti. Odnosno za serendipitet se često kaže da je „sretna slučajnost“, no on nije u potpunosti slučajan; mi možemo „pripremiti um“ na nenamjerna otkrića informacija i iskoristiti serendipne prilike kad se ukažu - $\mathrm{i}$ to prepoznavanjem vrijednosti naših otkrića. Iako se serendipitet ne može izravno kontrolirati, može se na njega utjecati; mogu se stvoriti uvjeti oblikovanjem fizičkih i digitalnih okruženja te okruženja za učenje. Serendipitet se ne može stvoriti na zahtjev, no mogu se stvoriti preduvjeti za njega. ${ }^{40}$ Erdelez dijeli korisnike na „nesusretače“ (engl. non-encounterers), ,povremene susretače“ (engl. occasional encounterers), „susretače“ (engl. encounterers) i ,supersusretače“ (engl. super-encounterers). „Nesusretači“ su oni kojima je teško prisjetiti se bilo kakva iskustva sa susretanjem informacija; kažu da je to nešto što vrlo rijetko doživljavaju. Druga su skupina ,povremeni susretači“, oni koji povremeno susreću informacije, ali ne vide u tim događajima više od sretnog slučaja. U trećoj su skupini „susretači“, ljudi koji prepoznaju da se često

39 Usp. Liu, F.; T. Jiang; Y. Chi. Online information encountering: modeling the process and influencing factors. // Journal of Documentation 71, 6(2015), str. 1135-1157. DOI:https://doi. org/10.1108/JD-07-2014-0100.

40 Usp. Makri, S. Supporting serendipity in digital information environments. //Accidental Information Discovery: Cultivating Serendipity in the Digital Age / ed. by Race, T.M.; Makri, S. Cambridge: Elsevier: Chandos Publishing, 2016. Str. 106. 
susreću s informacijama. Oni cijene takva iskustva, ali ne vide vezu između susreta s informacijama i drugih vidova svojeg informacijskog ponašanja. Konačno, četvrta su skupina korisnika „supersusretači“. Oni redovito susreću informacije i to percipiraju kao važan element svojega prikupljanja informacija. ${ }^{41}$ Dok Erdelez analizira načine na koje pojedinci doživljavaju serendipne situacije i prema tome ih grupira, Race i Makri govore o situacijama i čimbenicima na koje se može utjecati kako bi se potaknuo serendipitet, odnosno opisuju situacije u kojima je on ometan ili čak onemogućen. Oni objašnjavaju da omogućavanje serendipiteta ovisi jednako o osobnim, unutarnjim čimbenicima, kao i o vanjskim. Unutarnji su čimbenici oni kojima pojedinac može upravljati ili ih generira. Primjeri unutarnjih čimbenika uključuju individualni fokus i mentalno stanje, poznavanje predmeta ili žurbu i stres, odnosno bezbrižnost i opuštenost. Vanjski su čimbenici uzrokovani nečim izvan kontrole pojedinca. Primjeri vanjskih čimbenika uključuju organizacijsku strukturu, karakteristike zadataka i složenost ili dizajn fizičkih ili digitalnih informacijskih okruženja koja mogu olakšavati ili ometati serendipitet. ${ }^{42}$ Pojedinci se mogu „pripremiti“ za slučajno otkrivanje informacija usvajanjem ponašanja i stanja uma koje ga može potaknuti. Serendipitet se također može potaknuti uređenjem fizičkog i digitalnog okruženja. Utječući na čimbenike koji omogućuju serendipitet i način na koji ih pojedinci uklapaju u svoj poslovni i svakodnevni život, mogu se povećati izgledi za doživljavanje serendipiteta. ${ }^{43}$ Dakle iako se osobne karakteristike i osjetljivost na serendipitet mogu razlikovati u različitih osoba, moguće je pripremiti um, osvijestiti mogućnost serendipiteta, odnosno prilagoditi unutarnje i vanjske čimbenike koji utječu na serendipitet.

\section{Istraživanje serendipiteta $u$ informacijskim znanostima}

Kao što je ranije navedeno, istraživanje serendipiteta zahtjevno je, između ostalog, i zbog nemogućnosti kreiranja ponovljivih i kontroliranih uvjeta, no broj znanstvenih radova u tom području ipak raste. Prema Race i Makri, istraživanje slučajnog nailaženja na informacije u području informacijske znanosti grana se na tri široka i preklapajuća područja: opisivanje/definiranje serendipiteta (često u kontekstu otkrivanja informacija), razumijevanje interaktivnog prikupljanja informacija i dizajniranje digitalnih informacijskih okruženja koja stvaraju prilike za slučajno otkrivanje informacija. ${ }^{44}$ McCay-Peet i Toms predlažu šest poticaja

${ }_{41}$ Usp. Erdelez, S. Information encountering: it's more. Nav. dj. str 26-27.

42 Usp. Race, T. M.; S. Makri, S. Making room for serendipity. // Accidental Information Discovery: Cultivating Serendipity in the Digital Age / ed. by Race, T.M.; Makri, S. Cambridge: Elsevier: Chandos Publishing, 2016. Str. 15-25.

43 Usp. isto, str. 25.

44 Usp. Race, T. M. ; S. Makri. Introducing serendipity. // Accidental Information Discovery: Cultivating Serendipity in the Digital Age / ed. by Race, T.M.; Makri, S. Cambridge: Elsevier: Chandos Publishing, 2016. Str. 8. 
zbog kojih znanstvenici istražuju taj fenomen: korisnost serendipiteta pri interakciji u digitalnom, odnosno fizičkom okruženju, razvoj digitalnih okruženja koja će omogućiti korisnicima da naiđu na okidače serendipiteta u okolnostima preopterećenosti informacijama (engl. information overload), razbijanje filterskih mjehura (engl. filter bubbles) novim pristupima serendipitetu, razumijevanjem i prihvaćanjem pozitivnih iskustava vezanih uz serendipitet koji će koristiti pojedincima, grupama, mrežama i društvu, identificiranjem načina na koje korisnici mogu povećati mogućnosti serendipiteta vlastitim informacijskim ponašanjem ili duševnim stanjem u interakciji s digitalnim okruženjem i, na koncu, razumijevanjem fenomena serendipiteta. ${ }^{45}$

\section{Poticanje slučajnog nailaženja na informacije}

Prema Belkinu, dohvaćanje informacija smatra se oblikom traženja informacija u kojem je interakcija korisnika s tekstom središnji fenomen, na koji sustav za dohvaćanje informacija mora odgovoriti i koji mora podržavati. ${ }^{46}$ Serendipno dohvaćanje informacija događa se pri interakciji između korisnika bez prethodnih namjera i informacijskog sustava, kad korisnik u toj interakciji stječe korisne informacije ${ }^{47} \mathrm{U}$ takvim situacijama možemo reći da je došlo do slučajnog susreta s informacijama. McCay-Peet i Toms pri promišljanju sustava koji bi podržavali serendipitet kreću od pet elemenata kojima opisuju fenomen: (1) zapažanje nečeg neočekivanog, (2) opažatelja koji ima potrebne vještine kojima može prepoznati zanimljive nepravilnosti u zapaženom i (3) mentalni sklop koji će ga poticati da nastavi s promatranjem tijekom (4) vremena inkubacije potrebnog kako bi od zapažanja došlo do (5) neočekivanoga značajnog otkrića. Budući da elementi 2) i 3) nisu primjenjivi na sustave, već su isključivo ljudske karakteristike, preostala tri elementa uzeta su kao funkcionalni preduvjeti za računalnu podršku aktivnostima koje mogu voditi $\mathrm{k}$ serendipnim ishodima. Njihov je zaključak da do danas postoji vrlo malo primjera sustava koji zadovoljavaju sve tri temeljne funkcionalnosti. ${ }^{48}$ Toms je s druge strane pionirka u proučavanju načina poticanja slučajnog nailaženja na informacije na internetu. Pri evaluaciji preglednosti dviju vrsta sučelja za pretraživanje novina s hipertekstom primijetila je da je jedno od sučelja pružilo ispitanicima više prilika za slučajne susrete $\mathrm{s}$ informacijama od drugog sučelja. Studijom koja je slijedila načelno je pokazala da se može izgraditi sustav koji podupire slučajno pronalaženje informacija ${ }^{49}$ Race i Makri smatraju da sustavi

\footnotetext{
45 Usp. McCay-Peet L.; E. G. Toms. Nav. dj., str. 11-22.

46 Usp. Belkin, N. J. Interaction with texts: information retrieval as information-seeking behavior. // Information retrieval 93(1993), str. 56.

47 Usp. Toms, E. G. Nav. dj.

48 Usp. McCay-Peet L.; E. G. Toms. Nav. dj., str. 45.

49 Usp. Toms., E. G. Nav. dj.
} 
za dohvaćanje informacija ili digitalne knjižnice moraju biti dizajnirani tako da, osim podrške pri tipičnim zadacima pronalaženja informacija, moraju podržavati i različite vrste aktivnosti jednako kao što su mnoge generacije fizičkih knjižnica podržavale serendipne interakcije samim postavljanjem knjiga jednih pored drugih na police. Tako i digitalna knjižnica mora stimulirati znatiželju i potaknuti istraživanje kako bi korisnik mogao doći do zanimljivih otkrića. ${ }^{50}$ Iako je nemoguće „dizajnirati serendipitet" $u$ fizičkim informacijskim okruženjima kao što su knjižnice ili digitalnim kao npr. tražilice ili online knjižnične kataloge, ta okruženja mogu se dizajnirati kako bi se korisnicima olakšao dolazak do vlastitih slučajnih otkrića informacija. Knjižnični katalozi nove generacije i discovery internetski alati spajaju funkcije društvenih mreža u rasponu od dijeljenja (elektronička pošta, facebook) do stvaranja sadržaja (npr. oznake, recenzije). Te funkcije promiču raznolikost $\mathrm{u}$ organiziranim informacijskim strukturama (npr. katalozima, bazama podataka) i stvaraju potencijalne mogućnosti za serendipitet. Označavanje (engl. tagging) nudi višestruke puteve do slučajnog otkrivanja informacija. ${ }^{51}$ Pomoću tagova korisnici mogu naići na dodatne informacije ili terminologiju o temi koja ih zanima, a preko društvenih mreža mogu se povezati s drugim korisnicima i na taj način povećati mogućnosti za slučajno nailaženje na informacije.

Iako se serendipitet povezuje s pozitivnim učinkom, povećanje mogućih prilika za serendipitet ne vodi nužno pozitivnim ishodima. Digitalno okruženje s nebrojenim mogućnostima veza među informacijama s jedne strane pruža brojne mogućnosti za serendipne situacije, dok s druge strane dovodi do negativnog fenomena preopterećenosti informacijama. Kako bi se ublažila takva preopterećenost, konstruiraju se filterski mjehuri koji propuštaju samo one informacije za koje se smatra da su korisniku interesantne, no to dovodi do smanjivanja mogućnosti i prilika za serendipitet. Stoga McCay-Peets i Toms upozoravaju da rješavanjem jednog problema može doći do nastajanja novog te da su otvorena mnoga etička pitanja vezana uz poticanje serendipiteta. ${ }^{52}$ Naime namjerom da se poboljša korisničko zadovoljstvo kreiranjem filterskih mjehura zbog preopterećenosti informacijama može se uzrokovati situacija u kojoj korisnik nailazi samo na one informacije za koje je sustav „pretpostavio“ da korisniku odgovaraju, a „odabir“" sustava temelji se na korisnikovu prijašnjem informacijskom ponašanju. Budući da su algoritmi sustava za pretraživanje najčešće netransparentni, dolazi do situacija u kojima je korisnik izložen samo onim informacijama koje ionako već poznaje, odnosno idejama koje je već usvojio ili se s njima već slaže. Nameće se pitanje jesu li sustavi

\footnotetext{
50 Usp. Isto.

51 Usp. Race, T.; S. Makri. Serendipity in current digital information environments. // Accidental Information Discovery: Cultivating Serendipity in the Digital Age / ed. by Race, T.M.; Makri, S. Cambridge: Elsevier: Chandos Publishing, 2016. Str. 72-73.

52 Usp. McCay-Peet L.; E. G. Toms. Nav. dj., str. 22.
} 
za informacijsko pretraživanje programirani više ili manje etično ako filtriraju informacije koje pružaju prema korisniku nepoznatom algoritmu. ${ }^{53}$

$\mathrm{Na}$ vjerojatnost i uspješnost serendipnog nailaženja na informacije utječu unutarnji, odnosno ljudski čimbenici, kao i okruženje. Digitalni sustavi koji će podržavati serendipno nailaženje na informacije trebali bi i jedno i drugo uzeti u obzir. Nadalje, uz gore navedene funkcionalne preduvjete moraju biti zadovoljena i ranije spomenuta etička načela, kao i privatnost samih korisnika.

\section{Podučavanje serendipnom pronalaženju informacija}

Erdelez, Basic i Levitov navode da je nailaženje na informacije jedna od vrsta oportunističkog otkrivanja informacija te da je takvo informacijsko ponašanje osobito relevantno za istraživački proces u kontekstu obrazovanja. Autorice propituju je li moguće studente podučiti serendipitetu i pripremiti ih na susretanje s informacijama pri pretraživanju informacija vezanih uz njihov studijski rad. U svojem radu Potential for inclusion of information encountering within information literacy models objašnjavaju: „Sljedeći su modeli odabrani na osnovi njihove dugotrajnosti i zastupljenosti u literaturi: Proces traženja informacija Carol Kuhlthau (Kuhlthau's information search process), Velikih $6^{\mathrm{TM}}$ Eisenberga i Berkowitza (Eisenberg and Berkowitz' the Big6 ${ }^{\mathrm{TM}}$ ), Model istraživačkog procesa Striplingove i Pittsove (Stripling and Pitts' research process model), Model puta do znanja Marjorie Pappas i Ann Tepe ( Pappas and Tepe's pathways to knowledge model) i Istraživački ciklus Jamie McKenzie (Jamie McKenzie's research cycle). Ti su modeli odabrani za evaluaciju ne samo zbog njihove prepoznatosti [u struci] već i na temelju njihove međusobne različitosti i jedinstvenih karakteristika. "“54 Proučavajući svih pet modela, zaključile su da se ni u jednom od modela ne spominje serendipno pronalaženje informacija te su za svaki od njih identificirale mjesta gdje bi se podučavanje serendipnog pretraživanja moglo uvrstiti kako bi se studentima pomoglo da postanu svjesniji mogućnosti upravljanja takvim nepredvidivim prilikama unutar istraživačkog procesa ${ }^{55}$ Dok Erdelez, Basic i Levitov predlažu gdje unutar modela podučavanja informacijske pismenosti umetnuti poduku o serendipnom pronalaženju informacija, Race i Makri u poglavlju Teaching Serendipity knjige Accidental Information Discovery pružaju praktične savjete kako bi pomogli profesorima i knjižničarima pri izradi kolegija, istraživačkih zadataka i lekcija koje će uvoditi studente u serendipno nailaženje na informacije tijekom istraživačkog procesa. Oni obraćaju pozornost na načine rada u akademskim situacijama koji zahtijevaju empirijski upit, problemski pristup $i$ istraživanje informacijskih izvora. Govoreći o ta tri načina rada, autori istražuju gdje se može

\footnotetext{
53 Usp. isto, str. 22.

54 Erdelez, S.; J. Basic.; D. D. Levitov. Nav. dj.

55 Usp. isto.
} 
dogoditi serendipitet u svakom od modela i koje uloge nastavnici i knjižničari mogu igrati kako bi ga potaknuli. ${ }^{56}$ Budući da se studente često upućuje da tijekom istraživačkog rada ne gube fokus i da se drže odabrane teme, obraćanje pažnje na informacije koje nisu vezane uz temu, iako su potencijalno vrijedne, možda i neće podržati sami nastavnici. Potrebno je dakle osvijestiti i učenike, odnosno studente, ali i nastavnike i knjižničare o relevantnosti serendipnog nailaženja na informacije tijekom istraživačkog procesa.

\section{Zaključak}

U ovom radu predstavljena je etimološka pozadina engleske riječi serendipity te su prikazane vrste serendipiteta u povijesti znanosti te u informacijskim znanostima. Termini serendipitet, serendipno pronalaženje (otkrivanje, prikupljanje) informacija, nailaženje na informacije, nenamjerno stjecanje informacija, slučajno otkrivanje informacija i dr. u literaturi se upotrebljavaju naizmjenično kod opisivanja slučajnog nailaženja na korisne informacije. Iako je serendipitet nepredvidljiv, a time je i njegovo proučavanje metodološki zahtjevno, sve je više znanstvene literature u području informacijskog ponašanja koja se bavi tim fenomenom.

Također, u ovom radu objašnjen je pojam serendipiteta kao dijela informacijskog ponašanja, odnosno traženja informacija, te su predstavljeni modeli koji pobliže objašnjavaju taj koncept. Bez obzira na različitost percepcija o tome može li se i koliko utjecati na serendipitet, značaj proučavanja koncepta serendipiteta u informacijskom ponašanju jest u njegovoj primjeni u izgradnji sustava za pronalaženje informacija, kao i u podučavanju informacijskoj pismenosti.

Kod oblikovanja sustava za pronalaženje informacija nije moguće ugraditi funkcionalnost koja bi jamčila serendipno nailaženje na informacije, no dizajnom sustava moguće je utjecati na stvaranje okruženja koja mogu olakšati korisnicima dolazak do vlastitih slučajnih otkrića informacija. Korisnici, prvenstveno učenici i studenti, bit će dodatno osposobljeni za serendipno nailaženje na informacije tijekom istraživačkog procesa ukoliko u sklopu poduke informacijskoj pismenosti postanu svjesniji mogućnosti upravljanja nepredvidivim nailascima na korisne informacije. Koristeći se terminologijom preuzetom od Erdelez, moglo bi se reći da se odgovarajućom izobrazbom od „nesusretača“ i ,povremenih susretača“ mogu izgraditi „susretači“ i ,supersusretači“.

$\mathrm{Na}$ temelju obrađene literature, o budućnosti ovoga koncepta u daljnjim istraživanjima možemo pretpostaviti da će se kretati u smjeru ujednačavanja terminologije te daljnjeg artikuliranja tog oblika informacijskog ponašanja.

56 Usp. Race, T.; S. Makri. Nav. dj., str. 27-51. 


\section{LITERATURA:}

Accidental information discovery: cultivating serendipity in the digital age / ed. by Race, T.M.; Makri, S. Cambridge: Elsevier: Chandos Publishing, 2016.

Agarwal, N.K. Towards a definition of serendipity in information behaviour. // Information Research 20,3(2015). Dostupno na: http://informationr.net/ir/203/pape5674. html [citirano:2018-9-15].

Anić, V.; I. Goldstein. Rječnik stranih riječi, dotiskano 2. izd. Zagreb: Novi Liber, 2009.

Bates, M. Toward an integrated model of information seeking and searching. // New Review of Information Behaviour Research / Fourth international Conference on Information Needs, Seeking and Use in Different Contexts. Lisbon, Portugal, 2002. [citirano 2018-9-15]. Dostupno na: https://pages.gseis.ucla.edu/faculty/bates/articles/info_SeekSearch-i-030329.html.

Belkin, N. J., Interaction with texts: information retrieval as information-seeking behavior. // Information retrieval 93(1993), 55-56

Case, D. O. Looking for information: a survey of research on information seeking, needs, and behavior. Bingley, UK: Emerald, 2012.

Definition of serendipity. [citirano 2018-9-11]. Dostupno na: https://www.merriamwebster.com/dictionary/serendipity.

Erdelez, S. Investigation of information encountering in the controlled research environment. // Information Processing \& Management 40, 6(2004), 1013-1025. DOI: https://doi.org/10.1016/j.ipm.2004.02.002.

Erdelez, S. Information encountering. // Theories of Information Behavior / ed. by Fisher, K. , Erdelez, S. i McKechnie, L. Medford, N.J: Information Today Inc. 2005. Str. $179-184$.

Erdelez, S.; J. Basic; D. D. Levitov. Potential for inclusion of information encountering within information literacy models. // Information Research 16, 3(2011). Dostupno na: http://informationr.net/ir/16-3/paper489.html. [citirano:2018-9-15]

Erdelez, S. Information encountering: it's more than just bumping into information. // Bulletin of the American Society for Information Science and Technology, 25, 3(1999), 25-29. DOI: https://doi.org/10.1002/bult.118

Foster, A.; F. Nigel. Serendipity and information seeking: an empirical study. // Journal of Documentation 59, 3(2003), 321-40. DOI: https://doi. org/10.1108/00220410310472518.

Friedel, R. Serendipity is no accident. // The Kenyon Review 23(2001), 36-47.

Jiang, T.; F. Liu; Y. Chi. Online information encountering: modeling the process and influencing factors. // Journal of Documentation 71, 6(2015), 1135-1157. DOI:10.1108/jd-07-2014-0100. 
Makri, S. Supporting serendipity in digital information environments. //Accidental Information Discovery: Cultivating Serendipity in the Digital Age / ed. by Race, T.M.; Makri, S. Cambridge: Elsevier: Chandos Publishing, 2016. Str. 105-114.

McCay-Peet, L.; E. G. Toms. Researching serendipity in digital information environments / ed. by Gary Marchionini. San Rafael, California: Morgan \& Claypool Publishers, 2017.

Merton, R. K.; E. G. Barber. The travels and adventures of serendipity: a study in historical semantics and the sociology of science. Princeton, NJ: Princeton University Press, 2004.

Race, T. M.; S. Makri, S. Making room for serendipity. // Accidental Information Discovery: Cultivating Serendipity in the Digital Age / ed. by Race, T.M.; Makri, S. Cambridge: Elsevier: Chandos Publishing, 2016. Str. 14-26.

Ryder, P. M.; J. Nutefall. Teaching serendipity. //Accidental Information Discovery: Cultivating Serendipity in the Digital Age / ed. by Race, T.M.; Makri, S. Cambridge: Elsevier: Chandos Publishing, 2016. Str. 27-51.

Savolainen, R. Elaborating the conceptual space of information-seeking phenomena. // Information Research 20, 3(2015). Dostupno na: http://www.informationr.net/ir/213/paper720 [citirano: 2018-9-15].

Serendipity: how the vogue word became vague. [citirano 2018-9-11]. Dostupno na: http://livingheritage.org/serendipity.htm.

Spink, A.; C. Cole. Human information behavior: integrating diverse approaches and information use. // Journal of the American Society for Information Science and Technology 57, 1(2006), 25-35.

Toms, E. Serendipitous information retrieval. // Proceedings of the First DELOS Network of Excellence Workshop on Information Seeking, Searching and Querying in Digital Libraries. Zurich, 11.-12. prosinca, 2000. Str. 17-20. Dostupno i na: https://www. ercim.eu/publication/ws-proceedings/DelNoe01/3_Toms.pdf.

Williamson, K. Discovered by chance: the role of incidental information acquisition in an ecological model of information use. // Library \& Information Science Research 20, 1(1998), 23-40. DOI: https://doi.org/10.1016/S0740-8188(98)90004-4.

Williamson, K. Ecological theory of human information behavior. // Theories of Information Behavior / ed. by Fisher, K., Erdelez, S. i McKechnie, L. Medford, N.J: Information Today Inc. 2005. Str. 128-132.

Wilson, T. D. Human information behavior. // Informing Science: The International Journal of an Emerging Transdiscipline 3, 2(2000), 49-55.

Wilson, T. D. Models in information behaviour research. // The Journal of Documentation 55, 3(1999), 249-270. 